\title{
Effect of water deficit and sowing date on oil and protein contents in soybean co-inoculated with Azospirillum brasilense ${ }^{1}$
}

\author{
Alessandra Maria de Lima Naoe'2, Joênes Mucci Peluzio², \\ Leonardo José Motta Campos ${ }^{3}$, Lucas Koshy Naoe ${ }^{4}$, Evandro Reina ${ }^{2}$
}

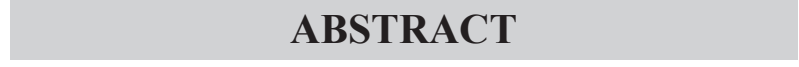

The soybean chemical composition is strongly influenced by genetic factors, as well as their interaction with the environment and management practices. Among the environmental factors, water deficit and temperature are those that most contribute to modify the chemical composition of beans, especially oil and protein contents. The present study aimed to assess the effects of co-inoculation with Azospirillum brasilense on soybean oil and protein contents. Two field experiments were carried out on different sowing dates. The design consisted of randomized blocks, in a split-split-plot arrangement, with four replications, including two irrigation depths (25\% and $100 \%$ of the ETc), two inoculation methods [Bradyrhizobium japonicum (strains Semia 5079 and Semia 5080) and Azospirillum brasilense (strains $\mathrm{AbV}_{5}$ and $\mathrm{AbV}_{6}+$ Bradyrhizobium japonicum)] and two cultivars (ANTA 82 and TMG 132). The co-inoculation did not affect the oil and protein contents of beans for any of the assessed management conditions. The water deficit in the reproductive stage, combined with the sowing dates, altered the oil and protein contents in both the assessed cultivars, showing, respectively, a higher average protein and oil content in the beans for the cultivars TMG 132 and ANTA 82.

KEYWORDS: Glycine $\max ($ L.) Merrill., rhizobacteria, abiotic stress.

\section{INTRODUCTION}

Soybean is an important source of oil and protein for human and animal nutrition (Hartman et al. 2011). Its seeds contain about $40 \%$ of protein and $20 \%$ of oil, accounting for $70 \%$ of the world protein from flour and $29 \%$ of vegetable oil consumption (ASA 2018).

Although the soybean chemical composition is expressed genetically, environmental factors also

\section{RESUMO}

Efeito do déficit hídrico e épocas de semeadura nos teores de óleo e proteína em soja coinoculada com Azospirillum brasilense

A composição química dos grãos de soja é fortemente influenciada por fatores genéticos, bem como sua interação com o ambiente e práticas de manejo. Entre os fatores ambientais, o déficit hídrico e a temperatura são os que mais contribuem para alterar a composição química dos grãos, especialmente o conteúdo de óleo e proteína. Objetivou-se avaliar os efeitos da coinoculação com Azospirillum brasilense sobre os teores de óleo e proteína da soja. Foram realizados dois experimentos em campo, em épocas de semeadura distintas. O delineamento utilizado foi em blocos casualizados, em esquema de parcelas subsubdivididas, com quatro repetições, composto por duas lâminas de irrigação (25 \% e 100 \% da ETc), dois métodos de inoculação [Bradyrhizobium japonicum (estirpes Semia 5079 e Semia 5080) e Azospirillum brasilense (estirpes $\mathrm{AbV}_{5}$ e $\mathrm{AbV}_{6}+$ Bradyrhizobium japonicum)] e duas cultivares (ANTA 82 e TMG 132). A coinoculação não afetou o teor de óleo e proteína dos grãos em nenhum dos manejos avaliados. O déficit hídrico no estádio reprodutivo, aliado às épocas de semeadura, alterou os teores de óleo e proteína nas duas cultivares avaliadas, apresentando, respectivamente, maior teor médio de proteína e óleo nos grãos para as cultivares TMG 132 e ANTA 82.

PALAVRAS-CHAVE: Glycine max (L.) Merrill, rizobactéria, estresse abiótico.

influence the concentration of components (Wang et al. 2015). Water deficit has been indicated as a decisive factor in the dynamics of forming and accumulating reserves in the seeds.

Mertz-Henning et al. (2018) observed that drought conditions during the reproductive phase of soybean seeds favor an increase in the protein content and a decrease in the oil content. Ghassemi-Golezani \& Lotfi (2013) also had similar

\footnotetext{
${ }^{1}$ Received: Nov. 11, 2020. Accepted: Feb. 17, 2021. Published: Mar. 11, 2021. DOI: 10.1590/1983-40632021v5166584.

${ }^{2}$ Universidade Federal do Tocantins, Palmas, TO, Brasil.E-mail/ORCID: alima@uft.edu.br/0000-0002-1271-8269, joenesp@uft.edu.br/0000-0002-9336-2072, evandroreina@uft.edu.br/0000-0002-4952-3465.

${ }^{3}$ Empresa Brasileira de Pesquisa Agropecuária (Embrapa Soja), Londrina, PR, Brasil. E-mail/ORCID: leonardo.campos@embrapa.br/0000-0002-8919-5398.

${ }^{4}$ Universidade Estadual do Tocantins, Palmas, TO, Brasil.E-mail/ORCID: lucas.kn@unitins.br/0000-0002-8662-4150.
} 
results with soybean plants under water deficit during the grain-filling stage. Albrecht et al. (2008) found an increased protein content under water deficit. However, they also observed an increased oil content at high temperatures.

The several environmental factors that affect the soybean chemical composition need further studies. The sowing dates are essential in this dynamic. The environmental variables change significantly between the planting dates, especially air temperature and water availability, which may modify the oil and protein yield per unit area (Bellaloui et al. 2011). Thus, it is imperative to look for management alternatives to reduce the adverse effects of the environment on crops.

Many studies have been developed on plant growth-promoting rhizobacteria, which is a potentially viable technology (Hungria et al. 2013, Zahedi \& Abbasi 2015, Zuffo et al. 2016). Regarding soybean, many countries have already employed Azospirillum brasilense associated with Bradyrhyzobium japonicum, a technique known as co-inoculation (Hungria et al. 2013).

Among the benefits attributed to coinoculation, many studies have already showed a better drought tolerance. Zahedi \& Abbasi (2015) observed that the morphological characteristics of soybean plants improved under water stress. Naoe et al. (2020) also found a positive response in the yield of soybean submitted to drought. However, there is a lack of concise data for the effects of plant-bacteria interaction on the chemical composition of beans.

The present study aimed to assess the effects of co-inoculation with Azospirillum brasilense on oil and protein contents, for two soybean cultivars submitted to water deficit on two sowing dates.

\section{MATERIAL AND METHODS}

The study was conducted at the Universidade Federal do Tocantins, in Palmas, Tocantins state, Brazil (10²' $46^{\prime \prime} \mathrm{S}, 48^{\circ} 21^{\prime} 37^{\prime \prime} \mathrm{W}$ and $260 \mathrm{~m}$ of altitude). Successive plantings were carried out on two sowing dates, with the soybean cultivars ANTA 82 and TMG 132. The first sowing date (D1) was June 2, 2016, and the second (D2) was July 1, 2016 , both in the off-season.

The regional climate is humid tropical, with a well-defined dry season (Aw) in the winter, which contributes to the high temperatures in the area
(Alvares et al. 2013). The average annual potential evapotranspiration is $1,500 \mathrm{~mm}$, with an average annual temperature and precipitation of $24.9^{\circ} \mathrm{C}$ and 1,642.9 mm, respectively (Roldão \& Ferreira 2019).

Figure 1 shows the climate data observed in the two experiments.

The average reference evapotranspiration (ETo) for the period was $151.12 \mathrm{~mm}$, as measured by the Penman-Monteith-FAO method (Allen et al. 1998), with cumulative precipitation of $127 \mathrm{~mm}$, as in the readings of the meteorological station installed in the experimental area.

The soil of the experimental area is classified as an Oxisol (Santos et al. 2013), with loam sandy texture, $\mathrm{pH} 4.9$, available concentrations of $\mathrm{P}$ and $\mathrm{K}$ of 3.00 and $26.00 \mathrm{mg} \mathrm{dm}^{-3}$ (ppm), respectively; $\mathrm{Ca}$ and $\mathrm{Mg}$ concentrations of 1.5 and $0.7 \mathrm{cmol}_{\mathrm{c}} \mathrm{dm}^{-3}$, respectively; and base saturation of $54.44 \%$. The mean soil bulk density was $1.55 \mathrm{~g} \mathrm{~cm}^{-3}$, with $82 \%$, $13 \%$ and $5 \%$, respectively, for sand, silt and clay. The volumetric moisture at field capacity and permanent wilting point were 0.33 and $0.12 \mathrm{~m}^{3}$, respectively.

Fertilization was carried out following the technical recommendations for soybean cultivation (Embrapa 2000) in soil prepared 15 days before planting. It consisted in the application of $400 \mathrm{~kg} \mathrm{ha}^{-1}$ of simple superphosphate, corresponding to $80 \mathrm{~kg}$ of $\mathrm{P}_{2} \mathrm{O}_{5} \mathrm{ha}^{-1}$, approximately.

The experimental design was randomized blocks, in a split-split-plot arrangement, with four replications. The plots consisted of two irrigation depths (I1: $100 \%$ of the ETc; I2: $25 \%$ of the ETc, starting at R3). The effects of the inoculation methods were evaluated in the split plots. The split-split

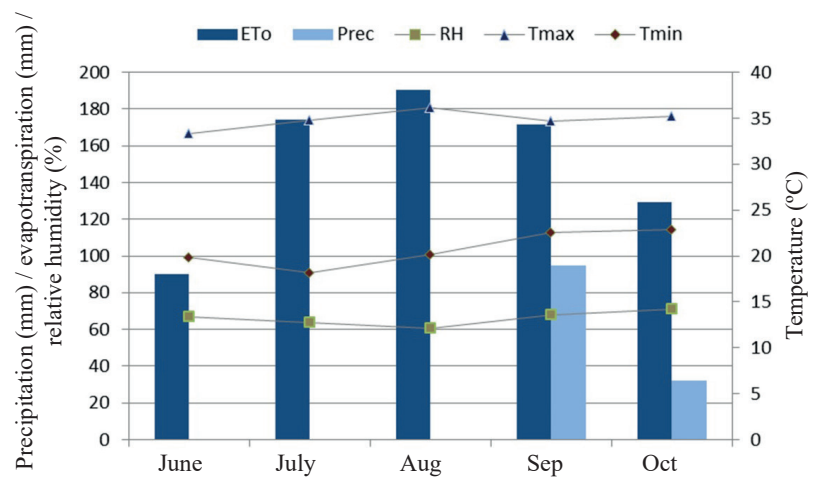

Figure 1. Average maximum (Tmax) and minimum (Tmin) temperatures, relative humidity $(\mathrm{RH})$, total reference evapotranspiration (ETo) and precipitation (Prec), in Palmas, Tocantins state, Brazil, in 2016. 
plots were used to assess the effect of the cultivars TMG 132 and ANTA 82 of medium and early cycles, respectively.

Two irrigation depths were adopted: a) full irrigation (I1), with a water depth of $100 \%$ of the ETc applied daily throughout the entire cycle; b) water deficit (I2), in which the treatments were subjected to water stress, starting at R3 (pod formation), and the daily depth applied was $25 \%$ of the ETc until the end of the cycle. Gava et al. (2016) indicated the beginning of the pod formation stage (R3), followed by grain filling, as the most sensitive stage to water deficit. Nunes et al. (2016) found adverse effects in soybean grown under severe water deficit (25\% of the ETc), in correlated Brazilian Savanna areas.

Irrigation was carried out by a dripping system with a flow rate of $1.7 \mathrm{~L} \mathrm{~h}^{-1}$. Drippers were placed every $0.2 \mathrm{~m}$, with four lines per treatment, in plots with $5.0 \mathrm{~m}$ long. The spacing was $0.5 \mathrm{~m}$ between rows and plants, with a density of 15 plants $\mathrm{m}^{-1}$. For the plot, the usable area of $3 \mathrm{~m}^{2}$ was considered, eliminating the border effect. On both sowing dates, the treatments were divided into inoculation methods and irrigation depths.

The inoculation methods were: a) inoculation with $600 \mathrm{~mL} 50 \mathrm{~kg}^{-1}$ of Bradyrhizobium japonicum (strains Semia 5079 and Semia 5080 - $5.0 \times 10^{9}$ viable cells $\mathrm{mL}^{-1}$ ); b) co-inoculation with $600 \mathrm{~mL} 50 \mathrm{~kg}^{-1}$ of Bradyrhizobium japonicum seeds $+400 \mathrm{~mL} \mathrm{ha}^{-1}$ of Azospirillum brasilense (strains $\mathrm{AbV}_{5}$ and $\mathrm{AbV}_{6}$ $2.0 \times 10^{8}$ viable cells $\mathrm{mL}^{-1}$ ). Both application methods were employed in the furrow immediately after sowing, using a backpack sprayer.

The plants were harvested manually after the R8 stage (full maturation). The soybean was then threshed from the pods in a stationary trailing machine, cleaned with the aid of sieves, dried under natural conditions, packed in paper bags and refrigerated until chemical analysis.

The oil and protein contents of the beans were determined by employing near-infrared spectroscopy (NIR Thermo Scientific equipment, Antaris II), in accordance with Oliveira et al. (2018).

The data were subjected to an individual analysis of variance, followed by the joint analysis when homogeneity of variances was verified. The means were grouped by the Scott-Knott test at $5 \%$ of significance. The statistical software Sisvar 5.0 (Ferreira 1998) was also employed.

\section{RESULTS AND DISCUSSION}

Only double and triple interactions were considered in the analysis of variance for the oil and protein contents (Table 1). Due to the low applicability of quadruple interactions, the degree of freedom of this interaction was adjusted to the final residue, thus increasing its accuracy, as recommended by Pimentel-Gomes (2009).

Among the effects tested in isolation, only cultivars (C) had a significant response to the oil and protein contents, showing that these characteristics are related to genetic factors, as demonstrated by $\mathrm{Li}$ et al. (2019). The sowing dates (D), irrigation depths (I) and inoculation methods (IM) did not individually affect the characteristics assessed in this study.

When the double I x D interaction was considered, only the protein content was significant, showing that this characteristic is more sensitive to environmental variations. According to Benzain \& Lane (1986), the protein content in grains depends on

Table 1. Joint analysis of variance for oil content (OC) and protein content $(\mathrm{PC})$ of soybean cultivars $(\mathrm{C})$ sown on two dates (D), under two irrigation depths (I) and two inoculation methods (IM).

\begin{tabular}{|c|c|c|c|}
\hline \multirow{2}{*}{ SV } & \multirow{2}{*}{ DF } & \multicolumn{2}{|c|}{ Mean square } \\
\hline & & $\mathrm{OC}(\%)$ & PC (\%) \\
\hline $\mathrm{D}$ & 1 & $1.20^{\mathrm{ns}}$ & $2.10^{\mathrm{ns}}$ \\
\hline Block & 3 & $0.06^{\text {ns }}$ & $0.12^{\text {ns }}$ \\
\hline Error 1 & 3 & $0.12^{\text {ns }}$ & $0.33^{\text {ns }}$ \\
\hline I & 1 & $1.147^{\mathrm{ns}}$ & $3.76^{\mathrm{ns}}$ \\
\hline$I \times D$ & 1 & $1.70^{\text {ns }}$ & $15.95 *$ \\
\hline Error 2 & 6 & $0.34^{\mathrm{ns}}$ & $0.87^{\text {ns }}$ \\
\hline IM & 1 & $1.42^{\text {ns }}$ & $0.045^{\text {ns }}$ \\
\hline IM x I & 1 & $5.65^{\text {ns }}$ & $6.65^{\mathrm{ns}}$ \\
\hline $\mathrm{IM} \times \mathrm{D}$ & 1 & $0.82^{\text {ns }}$ & $1.46^{\mathrm{ns}}$ \\
\hline IM x I x D & 1 & $0.48^{\mathrm{ns}}$ & $1.02^{\mathrm{ns}}$ \\
\hline Error 3 & 6 & $1.96^{\mathrm{ns}}$ & $3.70^{\text {ns }}$ \\
\hline $\mathrm{C}$ & 1 & $49.28 * *$ & $59.25 * *$ \\
\hline$C \times D$ & 1 & $45.98 * *$ & $49.51 * *$ \\
\hline $\mathrm{C} \times \mathrm{I}$ & 1 & $0.26^{\mathrm{ns}}$ & $0.04^{\mathrm{ns}}$ \\
\hline $\mathrm{C} \times \mathrm{IM}$ & 1 & $0.11^{\mathrm{ns}}$ & $0.00^{\mathrm{ns}}$ \\
\hline$C \times D \times I$ & 1 & $14.30 * *$ & $40.09 * *$ \\
\hline C x IM x I & 1 & $2.53^{\mathrm{ns}}$ & $4.45^{\mathrm{ns}}$ \\
\hline C x IM x D & 1 & $0.29^{\mathrm{ns}}$ & $0.15^{\mathrm{ns}}$ \\
\hline Error 4 & 31 & $0.97^{\mathrm{ns}}$ & $2.16^{\mathrm{ns}}$ \\
\hline $\mathrm{CV}_{1}(\%)$ & & 1.60 & 1.45 \\
\hline $\mathrm{CV}_{2}(\%)$ & & 2.62 & 2.37 \\
\hline $\mathrm{CV}_{3}(\%)$ & & 6.23 & 4.86 \\
\hline $\mathrm{CV}_{4}(\%)$ & & 4.40 & 3.71 \\
\hline
\end{tabular}


the environment four times more than on the cultivar, if compared to the oil content.

The double (IM x I; IM x D; C x IM) and triple (IM x I x D; C x IM x I; C x IM x D) interactions, in which the inoculation methods were considered, did not affect the oil or protein content in the beans. According to Hungria et al. (2013), Zahed \& Abassi (2016) and Naoe et al. (2020), co-inoculation improves the soybean agronomic characteristics and yield in adverse conditions such as drought. However, in the present study, the effects of this technique for increasing the soybean oil or protein content were not verified.

In the $\mathrm{C} x \mathrm{I}$ interaction, no significant effects were observed for oil and protein contents, indicating that the cultivars behaved similarly under different irrigation managements.

In the $\mathrm{C}$ x D x I interaction, significant effects were observed for the oil and protein contents, emphasizing that the chemical composition of beans occurs mainly due to genetic and environmental factors.

Table 2 shows the average rates of oil content of soybean originated from the $\mathrm{C} x \mathrm{D} x \mathrm{I}$ interaction.

In assessing the oil content between the irrigation depths on each sowing time and for each cultivar, it was observed that, for the cultivar ANTA 82, the I1 increased the oil content on D1, when the average temperatures were higher (Figure 1), corroborating the results by Mourtzinis et al. (2017). On D2, when the average temperatures were milder, the oil content increased during the I2 for this cultivar. Even though precipitation occurred in September and October (Figure 1), the water balance during the experiment guaranteed the water stress defined for the $25 \%$ of the ETc depth.

According to Li et al. (2019), although the oil content is genetically ruled, it is also strongly influenced by environmental factors. These results

Table 2. Average oil content of two soybean cultivars submitted to two irrigation depths (I), on two sowing dates.

\begin{tabular}{|c|c|c|c|c|}
\hline \multirow{3}{*}{ I } & \multicolumn{4}{|c|}{ Oil content $(\%)$} \\
\hline & \multicolumn{2}{|c|}{ ANTA 82} & \multicolumn{2}{|c|}{ - TMG 132} \\
\hline & D1 & D2 & D1 & D2 \\
\hline $\mathrm{I} 1$ & $23.32 \mathrm{aA} 1^{*}$ & $23.49 \mathrm{~b}$ & $.02 \mathrm{aA} 1$ & 20.4 \\
\hline $\mathrm{I} 2$ & $22.01 \mathrm{bB} 1$ & $25.12 \mathrm{aA} 1$ & $23.18 \mathrm{aA} 1$ & $20.19 \mathrm{aB} 2$ \\
\hline
\end{tabular}

* Averages followed by the same lowercase letter in the column (irrigation depths) and uppercase letter in the row (sowing dates) belong to the same statistical group by the Scott-Knott test at $5 \%$ of significance; while averages followed by the same number in the row (cultivars) belong to the same statistical group by the Scott-Knott test at $5 \%$ of significance. I1: irrigation depth 1 (100\% of the ETc); I2: irrigation depth 2 ( $25 \%$ of the ETc); D1: date 1; D2: date 2 . are in line with those found by Albrecht et al. (2008), Bruno et al. (2015) and Faria et al. (2018), who also observed an increased oil content in grains of plants grown under high temperatures and/or with less water availability in the grain-filling stage. However, Rotundo \& Westgate (2009) observed an overall negative impact of the water deficit on the oil content of soybean seeds in general.

The cultivar TMG 132 suffered no effects on its oil content between the irrigation depths on the two sowing dates (Table 2). This probably occurred because this cultivar has a better physiological and/or biochemical response to changes in water availability, so that the water factor, separately, may not have been determinant between the assessed conditions (D1 and D2). Naoe et al. (2020) observed a higher yield for the cultivar TMG 132 than for ANTA 82, even under conditions of water restriction. This condition of higher yield may be linked to a better photosynthetic efficiency and, consequently, a greater availability of energy for the plant, which may reduce the climatic influence on the seed chemical composition.

Water stress adversely impacts many physiological and biochemical aspects of plants, causing them to develop complex adaptations to adjust to a new environmental condition (Osakabe et al. 2014). These adaptations may lead to stomatal closure, repression of cell growth and reduced photosynthetic rate (Lin et al. 2018). The degree of response to environmental variations is related to the genotype, what may explain these results. Besides, medium-cycle cultivars, if compared to early-cycle cultivars, would have more time to recover from adverse environmental conditions.

Between the sowing dates (Table 2), the cultivar ANTA $82 \mathrm{kept}$ the same behavior within I1, that is, with a high water availability, and the temperature difference recorded between the dates (Figure 1) did not interfere in the biosynthesis of oil in the seeds. Assefa et al. (2019) carried out a broad study on the effects of sowing dates on the chemical composition of soybean and observed that low latitude areas may cause an absence of response to the oil and protein contents in grains, but the way each genotype interacts with environmental variables may vary in different planting windows.

Under water restriction (I2), D2 induced a higher average of oil content for the cultivar ANTA 82 (Table 2). However, the cultivar TMG 132 showed a higher oil content at D1, regardless of water 
availability. Although the oil content is strongly linked to genetic responses, this data reinforces the idea that temperature is also an important factor in the biosynthesis of this compound. Ren et al. (2009) observed a positive correlation between temperature and oil accumulation in the grains.

Assessing the cultivars, no significant differences were detected in the oil content on D1 for both irrigation depths, that is, both cultivars showed the same behavior under different water availabilities (Table 2). On D2, regardless of water availability, ANTA 82 had a higher oil content, when compared to TMG 132.

The oil content ranged between $22.01 \%$ and $25.12 \%$ for ANTA 82 and between $20.19 \%$ and $23.18 \%$ for TMG 132, indicating an average increase of $14 \%$ in the oil content in each cultivar. All higher averages of ANTA 82 were obtained in I2, corroborating Sepanlo et al. (2014), who also observed an increase in the oil content of soybean seeds under water deficit. In the present study, however, this occurred on different sowing dates, showing the different behavior of this cultivar under water deficit.

Table 3 shows the average protein content resulting from the triple $\mathrm{C} \times \mathrm{D} \times \mathrm{I}$ interaction.

No significant differences were detected for the cultivar TMG 132 on the two sowing dates in the irrigation depths. For ANTA 82, the double stress observed on D1, water deficit (I2) and temperature (Figure 1) favored the protein biosynthesis in the beans. On D2, the highest average for protein content was observed in I1 (Table 3).

Dornbos \& Mullen (1992) also observed an increase and a decrease in the protein and oil contents, respectively, at higher temperatures and less water availability. Thomas (2001) found an increase in the nitrogen concentration in mature seeds with the increase in temperature.

Table 3. Average protein content of two soybean cultivars submitted to two irrigation depths (I), on two sowing dates.

\begin{tabular}{|c|c|c|c|c|}
\hline \multirow{3}{*}{ I } & \multicolumn{4}{|c|}{ Protein content $(\%)$} \\
\hline & \multicolumn{2}{|c|}{ ANTA 82} & \multicolumn{2}{|c|}{ TMG 132} \\
\hline & D1 & D2 & D1 & D2 \\
\hline I1 & $38.09 \mathrm{bA} 2 *$ & $39.46 \mathrm{aA} 2$ & $40.17 \mathrm{aA} 1$ & $41.94 \mathrm{aA} 1$ \\
\hline $\mathrm{I} 2$ & $40.50 \mathrm{aA} 71$ & $35.98 \mathrm{bB} 2$ & $38.871 \mathrm{aB} 2$ & $42.00 \mathrm{aA} 1$ \\
\hline
\end{tabular}

* Averages followed by the same lowercase letter in the column and uppercase letter in the row belong to the same statistical group by the Scott-Knott test at $5 \%$ of significance; while averages followed by the same number in the row belong to the same statistical group by the Scott-Knott test at $5 \%$ of significance. I1: irrigation depth 1 ( $100 \%$ of the ETc); I2: irrigation depth 2 ( $25 \%$ of the ETc); D1: date 1; D2: date 2 .
For ANTA 82, when comparing the irrigation depths on both sowing dates, the protein content (Table 3) showed an inverse relationship with the oil content (Table 2). These results reinforce the negative correlation between these two variables (Chaudhary et al. 2015, Mertz-Henning et al. 2018). Thus, a factor that increases one of them will consequently decrease the other.

According to Pípolo (2002), this happens because of the competition for carbon skeletons to form cellular components. Hayati et al. (1996) claimed that changes in the balance of carbon and nitrogen supply during photosynthesis interfere with the chemical composition of the grain and might be the main mechanism to explain these variations related to environmental conditions. These conditions may include lack of water, nutrients and temperature, and may partly explain the variations observed in the cultivar ANTA 82.

When comparing the dates, ANTA 82 had a higher mean of protein content in I2 on D1. There was no difference between the dates assessed in I1, what also happened for the oil content (Table 2). In contrast, TMG 132 had a higher mean of protein content on D2 and under I2. In I1, there was no significant difference between the assessed dates. Again, an inverse relationship was observed between the protein (Table 3 ) and oil (Table 2) contents, for both the cultivars and sowing dates, in soybean grown under water stress.

According to Pípolo et al. (2015), the soybean protein content is strongly influenced by the environment, especially during the grain-filling period. However, this factor is genetically ruled, and the way that each cultivar responds to environmental changes influences the chemical composition of the grains. Pípolo et al. (2015) also described the influence of the environment on the supply of nitrogen to the plant and to the grain, which may indirectly influence the oil content of grains.

Among the cultivars, the response was different depending on the sowing date and irrigation management. On D1, the cultivar TMG 132 showed a better response to protein content in I1, while ANTA 82 showed a higher average in I2 (Table 3). On D2, regardless of water availability, TMG 132 registered higher averages of protein content, in contrast to what was found for oil content (Table 2) under the same conditions.

The protein contents ranged between $35.98 \%$ and $40.50 \%$ for ANTA 82 , what represents a difference 
of $12.56 \%$ between the averages of protein content. The protein content for TMG 132 ranged from $38.87 \%$ to $42 \%$, with a difference of $8.05 \%$ in the protein content (Table 3). It must be considered that a possible increase in the protein content under unfavorable environmental conditions may lead to a decrease in grain yield and quality. According to Mertz-Henning et al. (2018), the physical-chemical quality of grains may be damaged by severe drought conditions and a greater number of green grains with high acidity (Teixeira 2016).

The water deficit, associated with the temperatures, promoted different responses between the oil and protein contents in the assessed cultivars. Thus, the present study reinforced the influence of genetic and environmental factors on the soybean chemical composition.

\section{CONCLUSIONS}

1. The co-inoculation of Bradyrhizobium japonicum with Azospirillum brasilense did not significantly affect the soybean oil and protein contents;

2. The water deficit in the reproductive stage, combined with the sowing dates, altered the oil and protein contents in both the assessed cultivars, showing, respectively, a higher average protein and oil content in the beans for the cultivars TMG 132 and ANTA 82.

\section{REFERENCES}

ALBRECHT, L. P.; BRACCINI, A. L.; ÁVILA, M. R.; SUZUKI, L. S.; SCAPIM, C. A.; BARBOSA, M. C. Teores de óleo, proteínas e produtividade de soja em função da antecipação da semeadura na região oeste do Paraná. Bragantia, v. 67, n. 4, p. 865-867, 2008.

ALLEN, R. G.; PEREIRA, L. S.; RAES, D.; SMITH, M. Crop evapotranspiration: guidelines for computing crop water requirements. Rome: FAO, 1998.

ALVARES, C. A.; STAPE, J. L.; SENTELHAS, P. C.; GONÇALVES, J. L. M.; SPAROVEK, G. Köppen's climate classification map for Brazil. Meteorologische Zeitschrift, v. 22, n. 6, p. 711-728, 2013.

AMERICAN SOYBEAN ASSOCIATION (ASA). SoyStats: a reference guide to soybean facts and figures. St. Louis: ASA, 2018.

ASSEFA, Y.; PURCELI, L. C.; SALMERON, M.; NAEVE, S.; CASTELL, S. N.; KOVACS, P.; LICHT, $\mathrm{M}$. Assessing variation in US soybean seed composition (protein and oil). Plant and Soil Sciences Faculty Publications, v. 10, e298, 2019.

BELLALOUI, N.; READDY, K. N.; BRUNS, H. A.; GILEN, A. Soybean seed composition and quality: interactions of environment, genotype, and management practices. In: MAXWELL, J. (ed.). Soybeans: cultivation, uses and nutrition. New York: Nova Science Publishers, 2011. p. 1-42.

BENZAIN, B.; LANE, P. W. Protein concentration of grains in relation to some weather and soil factors during 17 years of English winter-wheat experiments. Journal of Science of Food and Agriculture, v. 37, n. 5, p. 435-444, 1986.

BRUNO, J. L.; SILVA, H. R.; MASSARO JUNIOR, F. L.; PRETE, C. E. C. Acúmulo de óleo em sementes de soja cultivadas in vitro e in vivo. Semina: Ciências Agrárias, v. 36, n. 5, p. 3085-3090, 2015.

CHAUDHARY, J.; PATIL, G. B.; SONAH, H.; DESHMUKH, R. K.; VUONG, T. D.; VALLIYODAN, B.; NGUYEN, H. T. Expanding omics resources for improvement of soybean seed composition traits. Front Plant Science, v. 6, e1021, 2015.

DORNBOS JUNIOR, D. L.; MULLEN, R. E. Soybean seed protein and oil contents and fatty acid composition adjustments by drought and temperature. Journal of the American Oil Chemists Society, v. 69, n. 3, p. 228-231, 1992.

EMPRESA BRASILEIRA DE PESQUISA AGROPECUÁRIA (Embrapa). Recomendações técnicas para a cultura da soja na região central do Brasil 2000/01. Londrina: Embrapa Soja, 2000. (Documentos, 146).

FARIA, L. A.; PELUZIO, J. M.; SANTOS, W. F.; SOUZA, C. M. de; COLOMBO, G. A.; AFFÉRRI, F. S. Oil and protein content in the grain of soybean cultivars at different sowing seasons. Brazilian Journal of Agricultural Sciences, v. 13, n. 2, p. 1-7, 2018.

FERREIRA, D. F. Sisvar: sistema de análise de variância para dados balanceados. Lavras: Ed. UFLa, 1998.

GAVA, R.; FRIZZONE, J. A.; SNYDER, R. L.; ALMEIDA, B. N.; FREITAS, P. S. L.; REZENDE, R. Estratégias de manejo de déficit hídrico na irrigação da cultura da soja. Brazilian Journal of Biosystems Engineering, v. 10, n. 3, p. 305-315, 2016.

GHASSEMI-GOLEZANI, K.; LOTFI, R. Influence of water stress and pod position on oil and protein accumulation in soybean grains. International Journal of Agronomy and Plant Production, v. 4, n. 9, p. 23412345, 2013.

HARTMAN, G. L.; WEST, E. D.; HERMAN, T. K. Crops that feed the world 2: soybean-worldwide production, use, and constraints caused by pathogens and pests. Food Security, v. 3, n. 1, p. 5-17, 2011. 
HAYATI, R.; EGLI, D. B.; CRAFTS-BRANDNER, S. $\mathrm{J}$. Independence of nitrogen supply and seed growth in soybean: studies using an in vitro culture system. Journal of Experimental Botany, v. 47, n. 294, p. 33-40, 1996.

HUNGRIA, M.; NOGUEIRA, M. A.; ARAÚJO, R. S. Coinoculation of soybeans and common beans with rhizobia and azospirilla: strategies to improve sustainability. Biology Fertility of Soils, v. 49, n. 7, p. 791-801, 2013.

LI, D.; ZHAO, X.; HAN, Y.; LI, W.; XIE, F. Genome-wide association mapping for seed protein and oil contents using a large panel of soybean accessions. Genomics, v. 111, n. 1, p. 90-95, 2019.

LIN, C.; GENTINE, P.; HUANG, Y.; GUAN, K.; KIMM, H.; ZHOU, S. Diel ecosystem conductance response to vapor pressure deficit is suboptimal and independent of soil moisture. Agricultural and Forest Meteorology, v. 250251, n. 1, p. 24-34, 2018.

MERTZ-HENNING, L. M.; FERREIRA, L. C.; HENNING, F. A.; MANDARINO, J. M. G.; SANTOS, E. D.; OLIVEIRA, M. C. N. D.; NEPOMUCENO, A. L.; FARIAS, J. R. B.; NEUMAIER, N. N. Effect of water deficit-induced at vegetative and reproductive stages on protein and oil content in soybean grains. Agronomy, v. 8, n. 3, p. 1-11, 2018.

MOURTZINIS, S.; GASPAR, A. P.; NAEVE, S. L.; CONLEY, S. P. Planting date, maturity, and temperature effects on soybean seed yield and composition. Agronomy Journal, v. 109, n. 5, p. 2040-2049, 2017.

NAOE, A. M. de L.; PELUZIO, J. M.; CAMPOS, L. J. M.; NAOE, L. K.; SILVA, R. A. Co-inoculation with Azospirillum brasilense in soybean cultivars subjected to water deficit. Revista Brasileira de Engenharia Agrícola e Ambiental, v. 24, n. 2, p. 89-94, 2020.

NUNES, A. C.; BEZERRA, F. M. L.; SILVA, R. A.; SILVA JÚNIOR, L. C.; GONÇALVES, F. B.; SANTOS, G. A. Agronomic aspects of soybean plants subjected to deficit irrigation. Revista Brasileira de Engenharia Agrícola e Ambiental, v. 20, n. 7, p. 654-659, 2016.

OLIVEIRA, M. A.; LORINI, I.; MANDARINO, J. M. G.; LEITE, R. S.; QUIRINO, J. R.; VILAS BOAS, R. L. P.; DELAFRONTE, B. Teores de óleo e proteina em grãos de soja, com diferentes manejos de percevejo, da colheita ao armazenamento, utilizando a espectroscopia no infravermelho próximo (NIR). Londrina: Embrapa Soja, 2018.

OSAKABE, Y.; OSAKABE, K.; SHINOZAKI, K.; TRAN, L-S. P. Response of plants to water stress. Plant Science, v. 5, n. 1, p. 1-8, 2014.

PIMENTEL-GOMES, F. Curso de estatística experimental. 15. ed. Piracicaba: Fealq, 2009.

PÍPOLO, A. C.; HUNGRIA, M.; FRANCHINI, J. C.; BALBINOT JUNIOR, A. A.; DEBIASI, H.;
MANDARINO, J. M. G. Teores de óleo e proteína em soja: fatores envolvidos e qualidade para a indústria. Londrina: Embrapa Soja, 2015. (Comunicado técnico, 86).

PÍPOLO, A. E. Influência da temperatura sobre as concentrações de proteina e óleo em sementes de soja (Glycine max (L.) Merril). 2002. Tese (Doutorado em Fitotecnia) - Escola Superior de Agricultura "Luiz de Queiroz”, Universidade de São Paulo, Piracicaba, 2002.

REN, C.; BILYEU, K. D.; BEUSELINCK, P. Composition, vigor, and proteome of mature soybean seeds developed under high temperature. Crop Science, v. 49, n. 3, p. 10101022, 2009.

ROLDÃO, A. F.; FERREIRA, V. O. Climatologia do estado do Tocantins - Brasil. Caderno de Geografia, v. 29, n. 59, p. 1161-1181, 2019.

ROTUNDO, J. L.; WESTGATE, M. E. Meta-analysis of environmental effects on soybean seed composition. Field Crops Research, v. 110, n. 2, p. 147-156, 2009.

SANTOS, H. G. dos; JACOMINE, P. K. T.; ANJOS, L. H. C. dos; OLIVEIRA, V. A. de; LUMBRERAS, J. F.; COELHO, M. R.; ALMEIDA, J. A. de; CUNHA, T. J. F.; OLIVEIRA, J. B. Sistema brasileiro de classificação de solos. 3. ed. revisada e ampliada. Brasília, DF: Embrapa, 2013.

SEPANLO, N.; TALEBI, R.; ROKHZADI, A.; MOHAMMADI, H. Morphological and physiological behavior in soybean (Glycine max) genotypes to drought stress implemented at pre- and post-anthesis stages. Acta Biologica Szegediensis, v. 58, n. 2, p. 1-5, 2014.

TEIXEIRA, C. T. S. Qualidade de sementes e caracterização de genótipos de soja visando à resistência ao complexo de percevejos. 2016. Tese (Doutorado em Fitotecnia) - Escola Superior de Agricultura "Luiz de Queiroz", Universidade de São Paulo, Piracicaba, 2016.

THOMAS, J. M. G. Impact of elevated temperature and carbon dioxide on development and composition of soybean seed. 2001. Thesis (Ph.D. in Plant Physiology) University of Florida, Gainesville, 2001.

WANG, J.; CHEN, P.; WRANG, D.; SHANNON, G.; ZENG, A.; ORAZALY, M.; WU, C. Identification and mapping of stable QTL for protein content in soybean seeds. Molecular Breeding, v. 35, e92, 2015.

ZAHEDI, H.; ABBASI, S. Effect of plant growth promoting rhizobacteria (PGPR) and water stress on phytohormones and polyamines of soybean. Indian Journal Agriculture Research, v. 49, n. 5, p. 427-431, 2015.

ZUFFO, A. M.; BRUZI, A. T.; REZENDE, P. M.; BIANCHI, M. C.; ZAMBIAZZI, E. V.; SOARES, I. O.; RIBEIRO, A. B. M.; VILELA, G. B. L. Morphoagronomic and productive traits of RR soybean due to inoculation via Azospirillum brasilense groove. African Journal of Microbiology Research, v. 10, n. 5, p. 438-444, 2016. 